\title{
DEVELOPING INTERCULTURAL BUSINESS COMPETENCE VIA TEAM LEARNING IN POST-PANDEMIC ERA
}

\author{
Tetiana Andrienko \\ Kyiv International University, Ukraine, \\ Westcliff University, California, USA \\ taniaandrienko@gmail.com \\ Vlad Genin \\ UOPX, Silicon Valley-Bay Area Campus, San Francisco, California, USA \\ vladgenin@yahoo.com \\ Iryna Kozubska \\ National Technical University of Ukraine "Igor Sikorsky Kyiv Polytechnic Institute”, Ukraine \\ kozubskair@gmail.com
}

To become successfully competitive in the globalised post-COVID 19 virtual business world, the engineering students, besides learning the English language for Specific Purposes as stipulated by the existing Syllabi, require purposed efforts for the formation of intercultural business communication competencies. This research, conducted successively in the USA and Ukraine combining observational and experimental methodology, aimed at studying the influence of team learning on the development of intercultural business competencies and skills highly desired and valued by employers, such as team building and teamwork, critical thinking, decision making, conflict prevention, and resolution, etc. The results were processed by combining qualitative and quantitative methods. Spanning in time from 2013 to 2020, the study proved the effectiveness of project work in learning teams for the development of intercultural competence and business communication skills. Team learning in virtual teams based on andragogical principles and methodology adapted by the authors to the needs of Ukrainian engineering students resulted in developing team building, teamwork, leadership, goal setting, planning, decision making, time management, creative and critical thinking, problem solving, conflict prevention and resolution, interpersonal and group communication and collaboration skills and competences, necessary for successful integration into the global workforce marketplace. Besides significant enhancement of intercultural business communication competencies, team learning resulted in raising Ukrainian undergraduate engineering students' motivation towards learning ESP, engagement in group and classwork, persistence towards successful graduation and gainful employment, and overall positive learning experiences.

Keywords: intercultural business competence; andragogy; team learning; ESP; post-pandemic employability; student motivation and persistence.

\section{Introduction}

One of the newest tendencies in the world centres of scientific and technical progress, including Silicon Valley high tech companies, is the transfer to the organisation of their production processes such as teamwork. The reason is the need to obtain promptly the cutting-edge results and to maintain competitiveness in tough market conditions. Therefore, in selecting their workforce, advanced companies attribute a great significance to teamwork, as well as other non-technical (communication) abilities and skills of prospective candidates (Blom and Saeki, 2011; Kassim and Ali, 2010; Matveev and Milter, 2004; Swartz et al., 2019; Irani, 2018).

This is why, the latest two decades saw the transformation of schools' of engineering, business, economics, applied science, etc. curricula to develop students' business communication skills, in particular, their ability to learn and work in teams, both on-site and online modalities. This is embedded in an andragogical approach to adult education (Loeng, 2018; McCauley et al., 2017; McGrath, 2009) and has resulted in the graduates' gainful employment, more successful careers and promotion, better work/life balance.

In the light of the newest developments of 2020 such as the COVID-19 global pandemic with extensive business closures and increasing transition of jobs to remote/online modes, the new challenge for higher education is not only to manage the processes of effective acquisition of fundamental professional knowledge and skills via online learning but ultimately, to prepare students for successful online business communication in

(C) Tetiana Andrienko, Vlad Genin, Iryna Kozubska. 2021. Published by Igor Sikorsky Kyiv Polytechnic Institute. This is an Open Access article distributed under the terms of the licence CC BY 4.0 
their prospective workplace, building their employability competencies, teamwork being one of the most important (Buheji and Buheji, 2020). Therefore, career readiness in the post-pandemic era implies the graduates' ability to work successfully in multicultural global teams, accomplishing their professional and organisational goals.

The greatest role in attaining this aim is attached to teaching and learning foreign languages because online makes state and national borders 'transparent', opening the opportunities for the future graduates to be employed in any country and work remotely. At the same time, the attention at the language classes has traditionally been focused on the formation of designated language and speech competencies and skills, disregarding differences in business cultures and business communication practices. Thus, the main task of polytechnic universities has always been to prepare engineering students for successful performance in their future work environment, which was seen as the same or identical everywhere in the world.

In the past, the strong technical skills of engineering graduates were of great value for manufacturing companies and could automatically guarantee their employment. Nowadays technological advances and globalisation trends generate a demand for the new generation of graduates, competent not only in their professional field but also in business communication with the representatives of other national and business cultures. These new qualities in demand are termed as 'soft skills'- "the intangible, non-technical, personalityspecific skills that determine one's strengths as a leader, facilitator, mediator, and negotiator" (Robles, 2012, p. 457). Among the most important of them are communication, collaboration, teamwork, creative and critical thinking, decision making, problem solving, work ethic, time management, planning, leadership, goal setting, and lifelong learning (Blom and Saeki, 2011; Kassim and Ali, 2010; Glaittli, 2018; Carpio et al., 2017).

A special place in this list is occupied by teamwork as it is considered to be one of the main soft skills presented in different classifications (Baird, 2019; Gibert, Tozer and Westoby, 2016; Moore and Pearson, 2017; Glaittli, 2018; Mayer and Bello, 2012; Chao and Pardy, 2017), one of the top 10 most-valued skills that Ukrainian employers require (Carpio et al., 2017) and is among modern global skills trends (International Labour Office, 2018). We believe that by practising teamwork through such activity as team projects the students can develop all the above-mentioned soft skills and gain an advantage in today's highly competitive qualified labour market. This can also be proved by the experience of Silicon Valley professor Dr. John Sperling (Sperling \& Tucker, 2005), who more than four decades ago pioneered his innovative university (University of Phoenix) based on andragogical principles of adult higher education. The core elements of his philosophy and approach were:

- Interactive teaching with in-class discussions and group activities vs traditional lecturing (which was limited to minilectures consuming no more than $10-15 \%$ of a class duration);

- Individual approach to student learning with comprehensive feedback on their home assignments, projects, presentations, and in-class activities;

- Shift from large to small adult student audiences;

- Implementation of Learning Teams (LTs) for enhancement of students' individual learning by team learning up to one-half of each educational course process;

- Integrated learning which included in-class sharing of knowledge, experience, real-life examples, and information contributed to a class by the professor, each individual student as well as members of student Learning Teams.

Successful implementation of the whole set of these principles and core elements became a true revolution in higher education of adults (first of all, working adults) and later on, of high school graduates. His innovative philosophy and methodology of higher education have been successfully and fruitfully adopted by a rapidly growing number of universities and colleges in the U.S. as well as many countries of the world. It has been satisfying current employers' demand for an effective workforce. It allowed the University of Phoenix to prepare for the U.S. and foreign countries over one million well-educated leaders, managers and professionals for corporations, organisations, startups and small businesses in practically all industries.

In the early stages of this concept development (before the beginning of the internet virtual communications era), LTs gathered together for their weekly meetings either at the university premises or one of their companies and worked on the preparation of the team assignments. In particular, they shared their newly acquired knowledge, professional experiences (both personal and from the outside world), discussed and analysed them, brainstormed suggested decisions and outcomes. Later on, upon the comprehensive and rapid development of internet communications and social networks, LTs shifted to virtual meetings. 
For the purposes of both self-control and university control, LTs submitted to the professor a Charter reflecting their meeting agenda, duration (academic hours), brief minutes, decisions made, as well as specifically participation and real contributions of each member of the LT.

As a result, LTs became a powerful tool in the preparation of the university graduates for advanced philosophy of innovative leadership and modern business administration methodology - today's and tomorrow's fundamental principles of existing and future corporations, small business, and startups. Therefore, students' learning process within LT work took approximately one-half of their weekly academic course duration and their individual work comprised another one-half. Such integration of students' individual and team learning allowed to:

- develop their practical knowledge and skills to the level required by real business life, in particular constantly increasing employers' needs and expectations in workforce solution and requirements to new job applicants;

- significantly increase the general quality of their higher education and preparedness for gainful employment;

- provide students - working adults with such additional benefits and conveniences as the reduction of inclass academic hours and increased mobility (especially those with frequent business travels, military personnel, etc.).

Based on the integration of students' individual and LT studies, the University of Phoenix graduated more than one million domestic and foreign leaders and professionals who have been in high demand at leading U.S. and international companies. For example, only Apple Computers employ more than one hundred University of Phoenix alumni.

This successful team learning practice must undoubtedly be implemented in Ukrainian universities and we think that an academic discipline within which team projects can be effectively implemented is ESP (English for Specific Purposes) as the aim of this subject is not merely to teach students special terminology and grammatical structures, but to prepare them for using the language in the intercultural teamwork environment (Zimmermann, 2010). In this study we focus on teamwork as both one of the most essential and desired skill sets, and, on the other hand, the way to develop major business communication competencies necessary for successful interaction in the global business environment in the post-pandemic era.

According to our hypothesis, team learning develops an array of business competencies critical for communicating across cultures, such as team building, teamwork, leadership, goal setting, planning, decision making, time management, creative and critical thinking, problem-solving, conflict prevention and resolution, interpersonal and group communication and collaboration, simultaneously enhancing students' engagement, internal motivation and overall learning experiences, resulting in growth in ESP and communication skills. Due to the differences in business cultures (Hall, 1976; Hofstede et al., 2005; Trompenaars and Hampden-Turner, 2020; Meyer, 2014), the processes and results of team exercises may vary across cultures, which brings about the importance of studying the transition of Ukrainian students to ways of business interaction that are typical for Western business culture through team learning. In today's situation, the cultivation of intercultural communicative competence has become the ultimate goal of foreign language teaching (Zheng, 2015), preparing engineering students for cross-cultural communicative interaction (Vitto, 2008, Gercar, 2019).

Therefore, the aim of this research is to study the influence of team learning on the formation of intercultural business competencies and skills as an essential part of soft skills enabling future professionals to perform successfully in a global/international business environment. This raises research questions and sets the respective research objectives:

- to study the employers' requirements, andragogical approaches to, and experiences of, team learning in the United States (as a prototypical Western business culture) as well as organisational aspects and methodology of team learning;

- based on differences in business cultures, to develop and test the virtual learning teamwork methodology aimed at the formation and/or enhancement of intercultural business communication competencies in Ukrainian undergraduate engineering students;

- to trace the correlation of team learning experiences with the acquisition of English language business communication skills and students' motivation, engagement, and satisfaction. 


\section{Methods}

\section{Research Design}

The research was conducted in two phases, combining observation and experimental methodology. The observational phase was realised between 2013 and 2015 at the University of Phoenix School of Business and Information Systems and Technology (IS\&T) at the Bay Area Campus (Silicon Valley/San Jose - Livermore Oakland learning centres, California USA), resulting in the formulation of hypothesis and development of the basic teaching methodology.

The methodology was approbated and the hypothesis tested in the course of the experimental phase which was implemented in the two leading universities' following learning locations: (1) University of Phoenix School of Business and Information Systems and Technology (IS\&T) at the Bay Area Campus (Silicon Valley/San Jose - Livermore - Oakland learning centres, California USA), hereinafter - UOPX, in 2016, and (2) National Technical University of Ukraine "Igor Sikorsky Kyiv Polytechnic Institute" (hereinafter - KPI), Faculty of Biomedical Engineering, Kyiv, Ukraine, in 2020.

\section{Participants}

The cohort of the observational phase included 246 undergraduate IT Engineering students, working both in on-campus and online modalities (116 women and 130 men).

The experimental phase included:

(1) at UOPX, 66 undergraduate IS\&T students (29 women and $37 \mathrm{men}$ ) in online programmes delivered via UOPX proprietary Online Learning System (OLS), enabling synchronous learning, as well as asynchronous online or off-line meetings of learning teams;

(2) at KPI, 64 students majoring in bioengineering (30 women and 32 men), who due to the COVID-19 quarantine measures studied online through synchronous Zoom class sessions and Telegram/Zoom asynchronous learning team meetings and communications with their professor.

In each cohort, the participants were divided into two groups - experimental and reference, approximately equal in academic achievements, numbering: at UOPX: experimental group - 32 students, reference group - 34 students; at KPI: experimental group - 32 students, reference group - 32 students.

Students involved in the experimental learning gave their informed consent to participate in the experiment.

\section{Instruments and Procedure}

During the observational study conducted in the USA, the researcher performed the monitoring of students' academic achievements, business communication skills development and overall learning experiences via Learning Team (LT) log-books, academic records, students' end-of-course surveys, as well as oral interviews with university professors, administrators, industry leaders (prospective and actual employers), business executives and alumni. This phase of research showed the high interest and motivation of employers, professors and students to team learning as an effective tool for forming the necessary soft skills. It also revealed the optimal size of the LTs ( 3 to 5 students), preferable assignments for teamwork (learning projects), frequency of meetings ( 1 to 2 meetings a week), and online or offline mode of LT meetings, at the students' discretion.

The experimental phase was conducted successively in the USA and Ukraine. Each of the experiments involved three stages: pre-experimental instruction, experiment and post-experimental assessment.

At the pre-experimental stage, the students of the experimental groups were instructed about the needs of their prospective employers in graduates with not only strong professional skills, but also 'soft' skill set, such as team building, teamwork, leadership, goal setting, planning, decision making, time management, creative and critical thinking, problem solving, interpersonal and group communication and collaboration, and explained the methodology of working at learning projects in LTs. The inclusion in the experimental group was voluntary, based exclusively on the students' understanding and informed consent to participate in the experiment.

During the experimental stage, all participants were given the assignments to prepare a theme project presentation in one of the course modules. The students in experimental groups were instructed to prepare their projects in LTs, using the LT methodology developed during the observational phase. The students in the reference groups prepared and presented their theme presentations individually.

At the post-experimental assessment stage, the quantitative assessment and student surveys were conducted to measure objective progress as well as changes in subjective attitudes. The results were interpreted and discussed to formulate the conclusions and recommendations as to the role of team learning in the development 
of critical intercultural business communication skills. The process and the results of experimental learning revealed differences in business cultures, which were given an explanation and respective recommendations formulated.

\section{Data Analysis}

The results of the experiments were processed combining qualitative and quantitative methods. Qualitative methods involved written and oral surveys to analyse students' self-assessment of progress in the development of business communication skills, as well as their learning experiences, motivation, and engagement. Quantitative methods included scaled assessment by the researches of the students' business communication and general communication skills, and the students' self-assessment, according to the methodology developed by the authors.

The results of experimental team learning were assessed independently by professors and students through written surveys. The surveys included questions of two types: (1) to measure objective progress and (2) to measure the students' subjective attitudes to team learning. The former offered a scaled assessment of business communication skills according to a 10-point scale, where "0" stands for "no progress at all" and " 10 " - for "outstanding progress" totalling the maximum of 100 points. Professors and students were asked to grade students' progress in the following business communication/'soft' skills, totalling the maximum of 100 points:

- Team building;

- Teamwork / team coordination;

- Knowledge management;

- Critical thinking;

- Problem solving;

- Conflict resolution;

- Presentation skills;

- Negotiation skills;

- Managing emotions / emotional intelligence;

- Time management.

The questions to measure subjective attitudes were open-ended questions asking students to share their experiences, emotions and attitudes, and provide recommendations for further improvement.

In addition to the above, in Ukrainian ESP learners the progress in the following English Language communication skills was measured by the teacher, evaluated at up to 20 points each, totalling the maximum of 100 points:

- Statement of one's ideas;

- Persuasion;

- Active and comprehensive listening;

- Requesting information;

- Expressing evaluations and emotions.

The individual assessment indices were then arithmetically averaged, respectively, for the Experimental Groups and Reference Groups. In comparative assessment, differences of 15 points (15\%) and above were considered significant.

\section{Results}

The critical advancement behind team learning as an andragogical innovation was an aspiration towards effective preparation of students to further gainful employment within teams in corporations, startups, small business/ entrepreneurship, including virtual teams.

While leading the University of Phoenix School of Business and IS\&T in San Francisco Bay Area - Silicon Valley, one of the researcher's main tasks was revealing the companies' and startups' real business needs in constant improvements and renewals of their workforce and, accordingly, requirements to job candidates - the university graduates. For this purpose, we have been constantly performing numerous meetings and interviews with prospective and current employers - leaders of both world-famous corporations (such as Cisco, Intel, Apple, Hewlett-Packard, Google, and others), industry leadership forums (such as Joint Venture Silicon Valley, Silicon Valley Leadership Group), and startups. 
In the overwhelming number of their answers to our questions on job candidates' expected talents, knowledge, and skill sets, the employers emphasised abilities for teamwork, since more and more companies are switching from old-fashion functional organisation of their processes to project-oriented organisation based on teams. The other highly valued skills included critical thinking, decision making, and intercultural business competence (Berlin, 2010; Irani, 2018; Mayer and Bello, 2012).

The team learning practice was heartily welcomed by foreign institutions but encountered unexpected difficulties: although inspired by the idea of teamwork and collaboration, the students could not self-organise to work effectively in a team (Duncan, 2013; Mayer and Bello, 2012). To ensure due attention to the cross-cultural differences we compared American and Ukrainian business cultures by two cultural dimensions most essential for the teamwork - individualism/collectivism and distance of power, which differ considerably between the USA and Ukraine (fig. 1) (Hofstede et al., 2005; Hofstede Insights, Belyh, 2019; Borysenko, 2017).

\section{Ukraine* $^{*}$ United States $\times$}

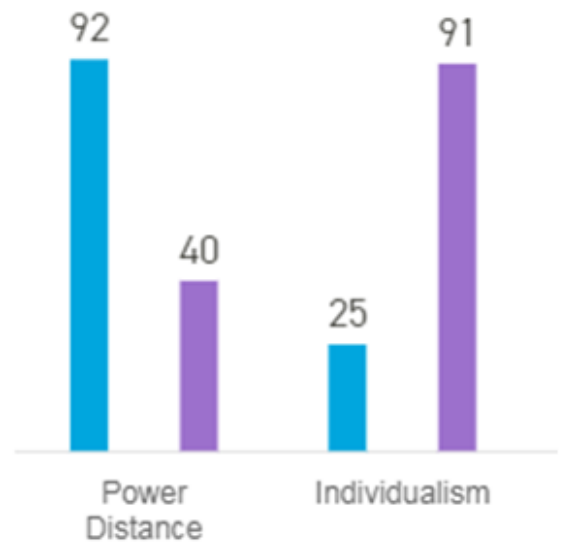

Figure 1. Individualism/collectivism and distance of power in the USA and Ukraine

(Quoted from: Hofstede Insights. https://www.hofstede-insights.com/country-comparison/ukraine,the-usa/)

On the scale of individualism/collectivism, the USA and Ukraine occupy very different positions. While the former is a prototypical individualist culture, number one for individualism (Hofstede et al, 2005; Trompenaars and Hampden-Turner, 2020), the latter is in the middle of the scale, sharing collectivism (as a post-communist state) with some features of individualism (Borysenko, 2017; Romanutskyi, 2014; Young, 2014).

As a prototypical example of individualist business culture, American culture is characterised by initiative, the ability to present one's stance and attend to the others', readiness to assume individual responsibility for the result of a person's work. At the same time, in collectivist cultures initiative is viewed as 'putting oneself forward' from the group and, therefore, is treated negatively. Individuals (employees or students) are used to being empowered by the 'collective' which will then hold shared responsibility. Countering the group's opinion and even making adjustments or clarifications is very unwelcomed (See: Hofstede et al., 2005, Belyh, 2019) (see Table 1). 
Table 1. Individualist vs Collectivist Behaviours in Education and Business Culture (adapted from Hofstede et al.)

\begin{tabular}{|c|c|c|}
\hline Criterion/attitude & Individualism & Collectivism \\
\hline Attitude to learning/education & $\begin{array}{l}\text { The assumption is that learning } \\
\text { in life never ends. The purpose } \\
\text { of learning is less to know how } \\
\text { to do than to know how to learn, } \\
\text { in order to learn to cope with } \\
\text { new, unknown, unforeseen } \\
\text { situations. There is a basically } \\
\text { positive attitude toward what is } \\
\text { new. }\end{array}$ & $\begin{array}{l}\text { Learning is seen as a one-time } \\
\text { process, reserved for young } \\
\text { people, who have to learn how to } \\
\text { do things in order to participate } \\
\text { in society. }\end{array}$ \\
\hline $\begin{array}{l}\text { Communication in classroom } \\
\text { and workplace }\end{array}$ & $\begin{array}{l}\text { Students/employees expect to be } \\
\text { treated as individuals and } \\
\text { impartially, regardless of their } \\
\text { background. Take initiative in } \\
\text { conversations. Do not hesitate to } \\
\text { interrupt their teacher/boss with } \\
\text { a question, objection, or to ask } \\
\text { for clarification. }\end{array}$ & $\begin{array}{l}\text { Students/employees do not speak } \\
\text { up unless sanctioned by the } \\
\text { group (even when the teacher } \\
\text { asks questions to the class, they } \\
\text { may feel too shy). } \\
\text { Shaming (that is, invoking the } \\
\text { group's honour) is an effective } \\
\text { way of correcting offenders. }\end{array}$ \\
\hline Handling differences & $\begin{array}{l}\text { Confrontations and open } \\
\text { discussion of conflicts are often } \\
\text { considered salutary, and face- } \\
\text { consciousness is weak or } \\
\text { nonexistent. }\end{array}$ & $\begin{array}{l}\text { Difference and confrontation } \\
\text { threaten losing faces and are } \\
\text { avoided. Students/employees } \\
\text { hesitate to express opinions in } \\
\text { the presence of out-group } \\
\text { members. }\end{array}$ \\
\hline Relations with the others & $\begin{array}{l}\text { It is immoral to treat some } \\
\text { people (clients, employees) } \\
\text { better than others. }\end{array}$ & $\begin{array}{l}\text { It is immoral not to treat one's } \\
\text { in-group members better than } \\
\text { others. }\end{array}$ \\
\hline Group formation & $\begin{array}{l}\text { Group formation among students } \\
\text { is much more ad hoc, operating } \\
\text { according to the task or } \\
\text { particular friendships and skills. } \\
\text { The assignment of joint tasks } \\
\text { leads more easily to the } \\
\text { formation of new groups. }\end{array}$ & $\begin{array}{l}\text { Students are dominated by the } \\
\text { existing in-group - out-of-group } \\
\text { differences, which may impede } \\
\text { the formation and functioning of } \\
\text { new groups for particular } \\
\text { purposes. }\end{array}$ \\
\hline Task-Relationship prevalence & $\begin{array}{l}\text { The task is supposed to prevail } \\
\text { over any personal relationships. }\end{array}$ & $\begin{array}{l}\text { The personal relationship } \\
\text { prevails over the task and should } \\
\text { be established first. }\end{array}$ \\
\hline
\end{tabular}

In the other dimension, a distance of power, the USA and Ukraine are also at different poles: in a democratic deliberative culture, decisions are taken through consultation, argumentation, seeking the best solution with bosses and employees having equal rights in sharing their opinions, doubts or remarks; 'grassroots' initiative is highly appreciated and often appealed to as the final argument. These are the features of low power distance that exists in the US business culture. In Ukraine with its high distance of power (Korostelina, 2013; Romanutskyi, 2014), the boss (in the classroom situation - the professor/instructor) is seen as a source of undisputed wisdom and ultimate power which can be neither doubted nor contested (without ramification). The virtues for employees/students are promptness, obedience and response to orders. The intention to do things one's own way is strongly discouraged both by bosses and colleagues (Hofstede et al., 2005; Meyer, 2014) (see Table 2). 
Table 2. Manifestations of Distance of Power in Education and Business Culture (adapted from Hofstede et al.)

\begin{tabular}{|c|c|c|}
\hline Criterion/attitude & Low Distance of Power & High Distance of Power \\
\hline Attitude to learning/education & $\begin{array}{l}\text { Students treat teachers as equals. } \\
\text { Teachers expect initiatives from } \\
\text { students in class. The quality of } \\
\text { learning depends on two-way } \\
\text { communication and the } \\
\text { excellence of students. }\end{array}$ & $\begin{array}{l}\text { Students give teachers respect, } \\
\text { even outside class. Teachers } \\
\text { should take all initiatives in class. } \\
\text { The quality of learning depends } \\
\text { on the excellence of the teacher. }\end{array}$ \\
\hline $\begin{array}{l}\text { Organisational } \\
\text { communications }\end{array}$ & $\begin{array}{l}\text { Subordinates and superiors } \\
\text { consider each other as } \\
\text { existentially equal; the } \\
\text { hierarchical system is just an } \\
\text { inequality of roles, established for } \\
\text { convenience and roles may be } \\
\text { changed, so that someone who } \\
\text { today is my subordinate may } \\
\text { tomorrow be my boss. } \\
\text { Organisations are fairly } \\
\text { decentralised with flat hierarchical } \\
\text { pyramids and limited numbers of } \\
\text { supervisory personnel. }\end{array}$ & $\begin{array}{l}\text { Superiors and subordinates } \\
\text { consider each other as } \\
\text { existentially unequal; the } \\
\text { hierarchical system is based on } \\
\text { this existential inequality. } \\
\text { Organisations centralise power as } \\
\text { much as possible in a few hands. } \\
\text { Subordinates expect to be told } \\
\text { what to do. There is a large } \\
\text { number of supervisory personnel, } \\
\text { structured into tall hierarchies of } \\
\text { people reporting to each other. }\end{array}$ \\
\hline Attitude to privileges & $\begin{array}{l}\text { According to privileges to higher- } \\
\text { ups is basically undesirable, and } \\
\text { everyone should use the same } \\
\text { parking lot, restrooms, and } \\
\text { cafeteria. Superiors should be } \\
\text { accessible to subordinates. }\end{array}$ & $\begin{array}{l}\text { Superiors are entitled to } \\
\text { privileges and contacts, between } \\
\text { superiors and subordinates are } \\
\text { supposed to be initiated by the } \\
\text { superiors. Separate restrooms, } \\
\text { parking places, and dining } \\
\text { halls/tables are designated for } \\
\text { bosses/professors. }\end{array}$ \\
\hline $\begin{array}{l}\text { Attitude to superiors and } \\
\text { decision making }\end{array}$ & $\begin{array}{l}\text { The ideal boss is a resourceful } \\
\text { (and therefore respected) } \\
\text { democrat. Subordinates expect to } \\
\text { be consulted before a decision is } \\
\text { made that affects their work, but } \\
\text { they accept that the boss is the } \\
\text { one who finally decides. }\end{array}$ & $\begin{array}{l}\text { The ideal boss in the } \\
\text { subordinates' eyes is a } \\
\text { benevolent autocrat or "good } \\
\text { father" whose authority and } \\
\text { orders are undisputed. After some } \\
\text { experiences with "bad fathers", } \\
\text { they may ideologically reject the } \\
\text { boss's authority completely, } \\
\text { while complying in practice. }\end{array}$ \\
\hline Abuse of power and law & $\begin{array}{l}\text { Organisations are supposed to } \\
\text { have structured ways of dealing } \\
\text { with employee complaints about } \\
\text { alleged power abuse. }\end{array}$ & $\begin{array}{l}\text { Being a victim of power abuse by } \\
\text { one's boss is just bad luck; there } \\
\text { is no assumption that there } \\
\text { should be ways of redress in such } \\
\text { a situation. If it gets too bad, } \\
\text { people may join forces for a } \\
\text { violent revolt. }\end{array}$ \\
\hline
\end{tabular}

As the result, UOPX established and enforced a strict policy: each course's learning process must be performed via both students' individual learning and team learning within LTs. Thus, at the beginning of each course, the professor offered students to form LTs and instructed them on major rules of teamwork.

It was empirically established that LTs consisting of 3 to 4 students were the most effective in terms of members' collaboration, intercultural communication, climate, active participation, inclusiveness, productiveness, management, and, what is very important, - enhancement, along with the individual part of the 
learning process, of the course's integrated learning outcomes. Each week within the course, LTs received the professor's assignments: performing research, writing up a paper, developing team project milestones, preparing in-class team oral presentations with visual aids, group activity, etc. The LT assignments' execution work included two major steps towards the following week's class: collective brainstorming, individual contributions, assignment preparation during the whole week, as well as in-class presentation performance (in any modality: on-campus, or online, or hybrid).

As a result of experimental team learning, significantly different progress between Experimental and Reference Groups was recorded both by the researchers and the students.

In the US cohort at UOPX, both the researcher and the students observed significant differences between the development of business communication skills in Experimental and Reference Groups as the result of experimental team learning, as shown in Table 3. Notably, the progress in teambuilding, knowledge management, presentation and negotiation skills, as well as time management, was higher in the student's average assessment, than in the researcher's, which proves the growth of the students' confidence in their achievements, overall satisfaction, and intention towards persistence in academic success.

Table 3. Progress in Business Communication Skills as the Result of Experimental Team Learning, UOPX

\begin{tabular}{|c|c|c|c|c|}
\hline \multirow{2}{*}{$\begin{array}{l}\text { Progress in Respective Skills } \\
\text { (of max } 10 \text { points) }\end{array}$} & \multicolumn{2}{|c|}{ Experimental Group } & \multicolumn{2}{|c|}{ Reference Group } \\
\hline & $\begin{array}{l}\text { Researcher's } \\
\text { Assessment, } \\
\text { averaged }\end{array}$ & $\begin{array}{c}\text { Students' } \\
\text { Assessment, } \\
\text { averaged }\end{array}$ & $\begin{array}{l}\text { Researchers' } \\
\text { Assessment, } \\
\text { averaged }\end{array}$ & \begin{tabular}{|c} 
Students' \\
Assessment, \\
averaged
\end{tabular} \\
\hline Team building & 9.2 & 9.7 & 3.9 & 3.2 \\
\hline Teamwork / team coordination & 9.4 & 9.2 & 3.1 & 3.4 \\
\hline Knowledge management & 7.7 & 9.1 & 4.7 & 4.4 \\
\hline Critical thinking & 8.1 & 8.2 & 6.8 & 6.1 \\
\hline Problem solving & 9.2 & 7.3 & 7.3 & 8.1 \\
\hline Conflict prevention/resolution & 8.7 & 8.1 & 5.8 & 3.7 \\
\hline Presentation skills & 7.4 & 7.8 & 7.1 & 7.5 \\
\hline Negotiation skills & 7.5 & 8.5 & 4.3 & 2.3 \\
\hline $\begin{array}{l}\text { Managing emotions / emotional } \\
\text { intelligence }\end{array}$ & 6.9 & 7.1 & 3.1 & 3.5 \\
\hline Time management & 5.3 & 7.2 & 5.7 & 5.1 \\
\hline Total (of max 100 points) & 79.4 & 82.2 & 51.8 & 47.3 \\
\hline
\end{tabular}

The relative progress was the most significant between Experimental and Reference Groups in such skills as team building, teamwork, knowledge management, negotiation skills, and managing emotions (fig. 2).

The qualitative analysis of the students' responses to open-ended questions asking to share their learning experiences, emotions, attitudes, and takeaways from team learning shows a notable growth in student engagement, positive emotional attitudes, motivation to further study and academic persistence, tightening of social ties and improvements in interpersonal and group communications. Some students derived ideas from team learning which contributed to their promotions in the workplace and creating their own small business.

Despite the undoubted success and widespread of team learning model in the US, the implementation of team learning encountered unexpected difficulties with students raised in different business cultures (Japanese, Scottish, German, Portuguese, etc ) (Bartel-Radic, 2006; Chao and Pardy, 2017; Duncan, 2018; Lee and Tony, 2007; Swartz, Barbosa and Crawford, 2019). Therefore, before implementing team learning in Ukraine, an insight into cultural differences was made, and the students were informed of the importance of teamwork skills and intercultural communication differences between Ukrainian and American (and, as a generalisation, western) business turnover and communication traditions. In particular, the attention was focused on such differences as individualism vs collectivism and distance of power (Hofstede et al., 2005; Meyer, 2014; Trompenaars and Hampden-Turner, 2020). 


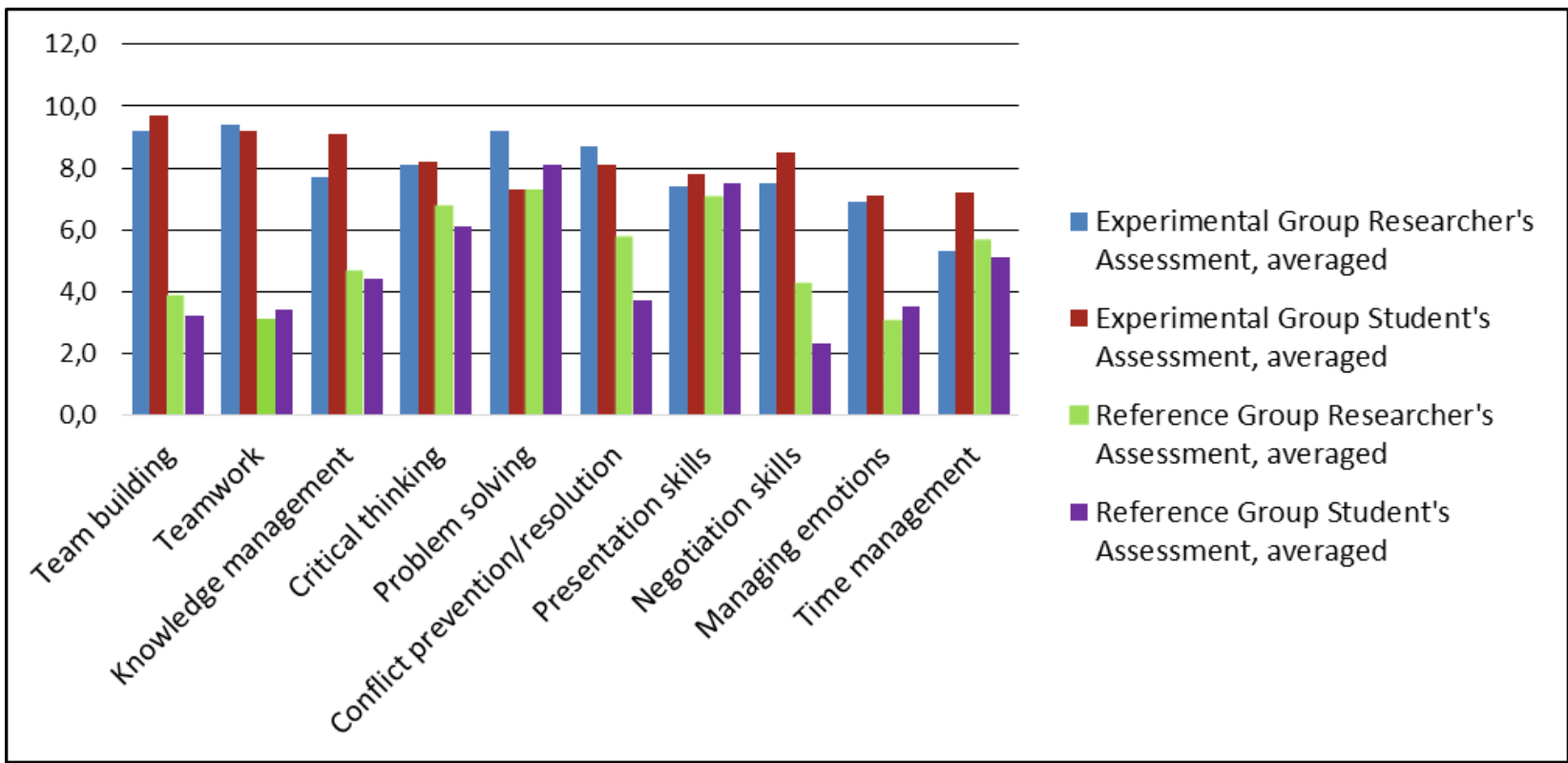

Figure 2. Progress in Business Communication Skills between Experimental and Reference Groups, UOPX

As a result of experimental team learning at KPI, both the researcher and students observed significantly higher development of business communication skills in the Experimental Group compared to the Reference Group, as shown in Table 4. As it was also observed, the students of the Experimental Group were, on average, more optimistic in their self-assessment than the researcher, especially in the assessment of their team building, teamwork, critical thinking, conflict prevention/resolution, and time management skills. At the same time, the students of the Reference Group were more pessimistic, giving themselves lower average points than the researcher in almost all skills. This, in our opinion, manifests the growth of self-confidence and conscious focus on 'soft' skills, understanding of their importance, and the need to work on their development in the Experimental Group, while in the Reference Group the understanding of the importance of the respective communication skills remained low.

Table 4. Progress in Business Communication Skills as a Result of Experimental Team Learning, KPI

\begin{tabular}{|l|l|l|l|l|}
\hline \multirow{2}{*}{$\begin{array}{l}\text { Progress in Respective Skills } \\
\text { (of max 10 points) }\end{array}$} & \multicolumn{2}{|c|}{ Experimental Group } & \multicolumn{2}{c|}{ Reference Group } \\
\cline { 2 - 5 } & $\begin{array}{c}\text { Researcher's } \\
\text { Assessment, } \\
\text { averaged }\end{array}$ & $\begin{array}{c}\text { Students' } \\
\text { Assessment, } \\
\text { averaged }\end{array}$ & $\begin{array}{c}\text { Researchers' } \\
\text { Assessment, } \\
\text { averaged }\end{array}$ & $\begin{array}{c}\text { Students' } \\
\text { Assessment, } \\
\text { averaged }\end{array}$ \\
\hline Team building & 7.9 & 9.6 & 2.9 & 2.1 \\
\hline Teamwork / team coordination & 7.2 & 9.1 & 3.1 & 2.7 \\
\hline Knowledge management & 6.7 & 6.2 & 4.9 & 4.2 \\
\hline Critical thinking & 6.2 & 7.8 & 4.7 & 3.1 \\
\hline Problem solving & 6.7 & 8.2 & 6.1 & 3.8 \\
\hline Conflict prevention/resolution & 6.4 & 7.7 & 5.8 & 3.4 \\
\hline Presentation skills & 8.3 & 7.4 & 6.7 & 5.5 \\
\hline Negotiation skills & 7.7 & 6.2 & 3.9 & 3.2 \\
\hline $\begin{array}{l}\text { Managing emotions / emotional } \\
\text { intelligence }\end{array}$ & 6.1 & 6.8 & 3.3 & 2.3 \\
\hline Time management & 7.2 & 5.3 & 7.1 & 5.1 \\
\hline Total (of max 100 points) & $\mathbf{7 0 . 4}$ & $\mathbf{7 4 . 3}$ & $\mathbf{4 8 . 5}$ & $\mathbf{3 5 . 4}$ \\
\hline
\end{tabular}


The relative progress was the most significant between Experimental and Reference Groups in such skills as team building, teamwork, critical thinking, conflict prevention/resolution, and managing emotions (fig. 3).

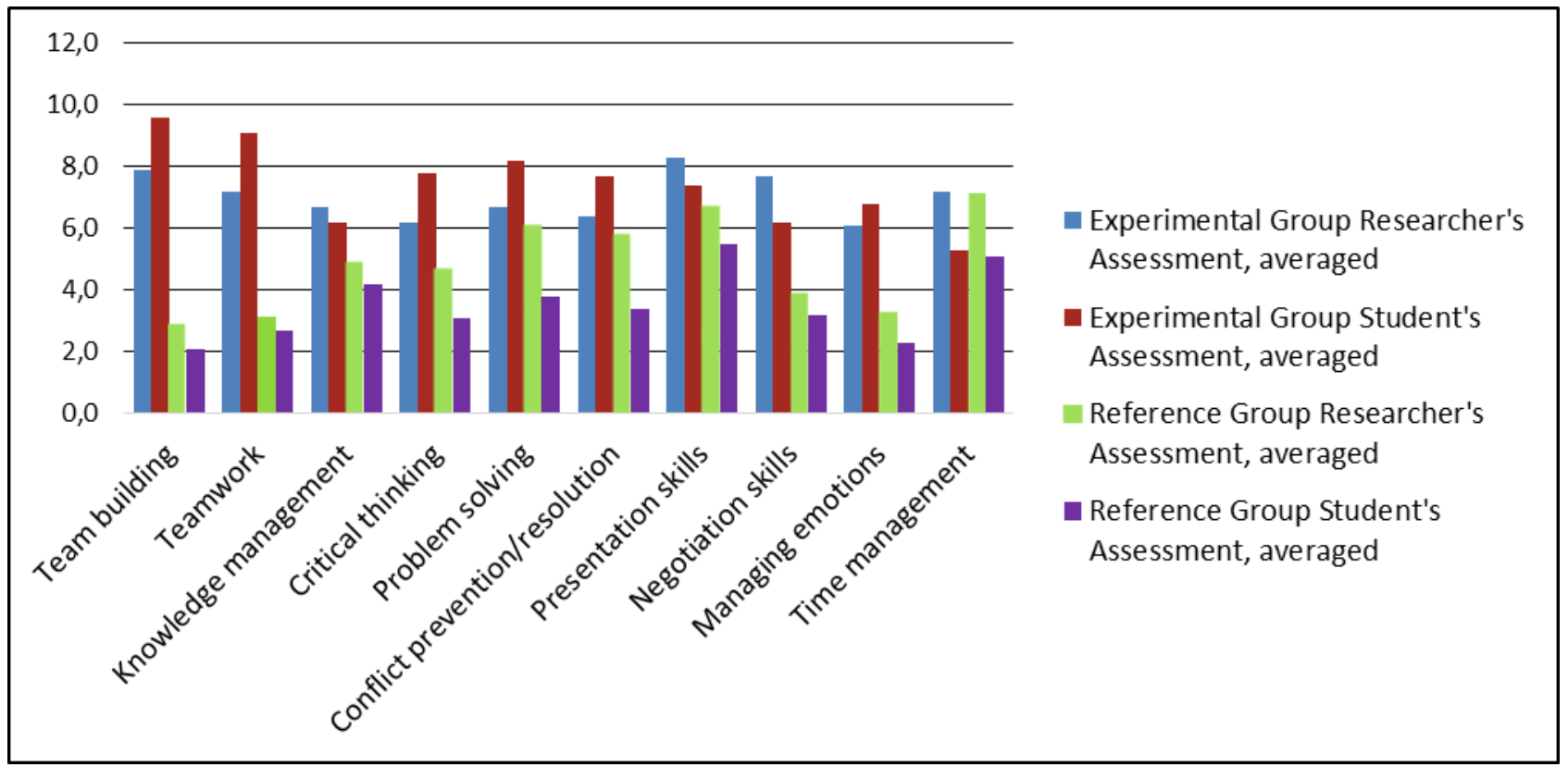

Figure 3. Relative Progress in Business Communication Skills between Experimental and Reference Groups, KPI

The qualitative analysis of the students' responses to open-ended questions showed the shift in their attitudes towards learning and future work: the growth of their personal responsibility, independence and interdependence, tightening or creating new social and emotional ties. Describing their emotional experiences, the students pointed out initial difficulties in handling differences of opinions and negative emotions, which later resulted in a better understanding of how to gain from differences and higher emotional intelligence. Overall, the students' positive subjective opinions were almost unanimous, with the indication that LT methodology opened them new opportunities and a better understanding of their talents, gave them professional collaboration experiences, and inspired them for further learning and research. All the participants of the experiment said they would prefer if team learning became their regular practice.

The progress of the Ukrainian ESP learners in the English Language communication skills was on average slightly higher in the Experimental Group, in particular, in such skills as active and comprehensive listening, persuasion, and expressing evaluations and emotions, where the differences with the Reference Group exceeded $15 \%$. This proves the positive effect of team learning on the development of foreign language communication skills.

\section{Discussion}

Results obtained further support the idea that teamwork and team projects are beneficial for students for developing intercultural business competencies and skills. Our findings are in good agreement with other studies (Kalytchak et al., 2015; Hutchison, 2015; Whatley, 2016; Burton et al., 2016) which claim that group work is one of the most useful ways of learning about collaboration and communication, shared responsibility, critical thinking, problem solving, project planning, time management, and self-direction.

For the interest of this paper, our aim was to scrutinise the impact of team learning on the formation of intercultural business competencies and soft skills which we believe will enable future specialists to perform successfully in a global/international business environment. Within this goal, before the experiment, we considered the most essential for the teamwork cross-cultural differences in Ukrainian and American business cultures which could become a stumbling block in the transition of Ukrainian students to the ways of business interaction that are typical for Western business culture. 
Due to the above-mentioned differences in Ukrainian and American business cultures, we expected certain difficulties for the Ukrainian students to engage in teamwork smoothly. To proactively meet the anticipated challenges, before the experimental team learning, the students were explained the differences in business cultures and the importance of such traits and behaviours as self-presentation, initiative, openness to other's opinions, reciprocal responsibility, collaboration and compromise, emotional intelligence,etc. Additionally, the researcher promoted the idea of diversity as an asset, encouraging students to value each other's unique talents and ideas, share their knowledge, control negative emotions and be self-organised and supportive.

Our expectations were later confirmed by the students' questions and requests for the professor's involvement. However, after the initial explanation and assistance on the part of the professor/researcher, the students developed a better understanding of team building and team collaboration practices and were further able to efficiently cooperate, working over team projects on their own.

The results of the quantitative analysis show a significantly higher growth of all the measured business communication skills in the Experimental Group compared to the Reference Group. What is even more interesting, in relative terms, the progress of the Ukrainian students was higher than that of the American students which we explain by the fact that in the Ukrainian Reference Group the respective skills remained on a lower level, since they are neither required nor supported in Ukrainian business and academic culture, while in the US the whole course of educational and working experiences requires team building and team working, selfpresentation, collaboration, negotiation, management of emotions and other business communication skills typically described as 'soft skills'. Therefore, an important conclusion derived from this experience is that to become the effective users of English for Specific Purposes, or 'Business English', the students, besides learning language and communication skills as stipulated by the existing Syllabi, require continuous attention and purposed efforts aimed at the formation of business communication understanding and competences. The effective tool for the development of business communication skills, as demonstrated by our experiment, is project work in LTs. Qualitative analysis also shows the growth of student engagement, persistence and motivation; most of the students gained from team learning both through enhanced learning experiences and higher intercultural business competence which increases their opportunities for gainful employment.

However, despite all the benefits team projects are not so common in the teaching practice of ESP in Ukrainian universities. We think it may be caused by a number of reasons: 1) the low priority given to ESP in timetabling - engineering students have only two hours of English a week and it is believed that team project organisation and implementation demands a fair amount of time; 2) students are not aware of effective team project management and prefer to work over the tasks individually; 3 ) the topics of the project work during ESP classes are closely connected with specific engineering knowledge and skills but an ESP teacher may feel the lack of such knowledge, being mainly a language teacher; 4) both teachers and students do not fully realise the importance of developing intercultural competences and soft skills through team projects in the ESP class. By our experimental research, we have proved the importance and sufficiency of implementing LT projects into the practice of ESP teaching on a routine basis, along with additional attention to the explanation of intercultural differences and formation of the respective behaviours. This should form the employer-required business communication ('soft') skills, increasing the graduates' employability in the post-pandemic virtual settings.

\section{Limitations}

Being a pioneering study of using LT projects for the formation of the Ukrainian engineering students' intercultural business competence and readiness to integrate into the Western business environment, this study lacks prior research on the topic and reliable data for comparison and discussion. To overcome this limitation, we considered experiences and research data on the problem obtained in economically and culturally varied settings, including the US, Japan, Russia, Ghana, Australia, India, Malaysia, Scotland, etc. We view this limitation as a prospect for further research and practical approbation in other polytechnic institutions with engineering students and students of other specialisations.

\section{Conclusions}

To become effective users of English for Specific Purposes, or 'Business English', the students, besides learning language and communication skills as stipulated by the existing Syllabi, require continuous attention and purposed efforts aimed at the formation of business communication understanding and competencies. Among highly desired and valued skills, the employers quoted abilities for teamwork, due to switching from 
functional organisation of processes to project-oriented organisation based on teams as well as critical thinking, decision making, intercultural business competence, and the like.

As demonstrated by our experiment, the effective tool for the development of business communication skills is project work in learning teams. Team learning in virtual teams (which became a necessity due to COVID-19), based on andragogical principles and methodology adapted by the authors to the needs of Ukrainian engineering students, results in developing business competencies, such as team building, teamwork, leadership, goal setting, planning, decision making, time management, creative and critical thinking, problem solving, conflict prevention and resolution, interpersonal and group communication and collaboration necessary for integration into the global workforce marketplace. Besides significant enhancement of intercultural business communication competencies, team learning resulted in raising Ukrainian undergraduate engineering students' motivation towards learning ESP, engagement in group and classwork, persistence towards successful graduation and gainful employment, and overall positive learning experiences.

Our findings suggest the importance and sufficiency of implementing learning team projects into the practice of ESP teaching on a routine basis, along with additional attention to the explanation of differences in business cultures and formation of the respective culturally competent behaviours.

\section{References:}

Baird, M. (2019). Project based learning to develop $21^{\text {st }}$ century competencies. In R. Power (Ed.), Technology and the curriculum: Summer 2019. Retrieved from https://techandcurr2019.pressbooks.com/.

Bartel-Radic, A. (2006). Intercultural Learning in Global Teams. Management International Review, 46(6), 647-678. https://doi.org/10.1007/s11575-006-0121-7

Belyh, A. (2019). Understanding Cultures \& People with Hofstede Dimensions. Retrieved from https://www.cleverism.com/understanding-cultures-people-hofstede-dimensions

Berlin, L. (2010). Robert Noyce, Silicon Valley, and the Teamwork Behind the High-Technology Revolution. OAH Magazine of History, 24(1), 33-36. https://doi.org/10.1093/maghis/24.1.33

Blom A., \& Saeki, H. (2011). Employability and skill set of newly graduated engineers in India. Policy research working papers. Retrieved from https://elibrary.worldbank.org/doi/pdf/10.1596/1813-9450-5640. https://doi.org/10.1596/1813-9450-5640

Borysenko, L. (2017). Ukrainian culture: individualism or collectivism? Frontier problems of modern psychology (conference proceedings) (pp.59-63). Kherson. Retrieved from https://borysenko-conf-oct-preprint-2017-06-28T16_56_06.748Z\%20(1).pdf

Buheji, M., \& Buheji, A. (2020). Planning Competency in the New Normal-Employability Competency in Post-COVID-19 Pandemic. International Journal of Human Resource Studies, 10(2). 237-251.https://doi.org/10.5296/ijhrs.v10i2.17085.

Burton, S., Thoms, C., Burrel, D., Jackson, K. B., Bessette, D., \& White, Y. Developing Learner Skills in the $21^{\text {st }}$ Century. In J. Whatley \& C. Nerantzi (Eds.), (2016), Teaching with team projects in higher education. Santa Rosa, CA, USA: Informing Science Press.

Carpio, X., Kupets, O., Muller, N., \& Olefir, A. (2017). Skills for a modern Ukraine. Retrieved from https://openknowledge.worldbank.org/handle/10986/25741

Chao, I. T., \& Pardy, M. C. (2017). Your Way or My Way? Integrating Cultural Diversity into Team-based Learning at Royal Roads University. In S. L. Grundy, D. Hamilton, G. Veletsianos, N. Agger-Gupta, P. Márquez, V. Forssman \& M. Legault (Eds.), Engaging Students in Life-Changing Learning. Retrieved fromhttps://learningandteachingmodel.pressbooks.com/chapter/yourway-or-my-way-integrating-cultural-diversity-into-team-based-learning-at-royal-roads-university/

Duncan, B. (2013). Assessing the Viability of Team Learning with Remedial Students in a Japanese College (Doctoral Dissertation). Fielding Graduate University, USA.

Duncan, B. (2018). Small-group learning research illuminates the Hawthorne effect as a tool for scaffolding remedial student development toward interdependence. Kyiv International University Higher Education Journal. Retrieved from https://kymu.edu.ua/upload/pdf_files/small-group_learning_research.pdf

Hall, E.T. (1976). Beyond culture.Garden City, N.Y: Anchor Press.

Hofstede G., Hofstede G. J., Minkov M. (2005). Cultures and Organizations: Software of the Mind. London: McGrawHill.

Hofstede Insights (n.d.). Retrieved from https://www.hofstede-insights.com/country-comparison/ukraine,the-usa/

Hutchison, D. (2015). Project-Based Learning: Drawing on Best Practices in Project Management. Retrieved from http://www.edu.gov.on.ca/eng/literacynumeracy/inspire/research/WW_BestPractices.pdf

Gercar, V. (2019). Intercultural fluency, a critical soft skill in today's global world. Retrieved fromhttps://news.illinoisstate.edu/2019/03/intercultural-fluency-a-critical-soft-skill-in-todays-global-world/

Gibert, A., Tozer, W.C., \& Westoby, M. (2017). Teamwork, Soft Skills, and Research Training. Trends in Ecology \& Evolution, 32(2), 81-84. https://doi.org/10.1016/j.tree.2016.11.004.

Glaittli, M. (2018). Soft Skills in High School (Doctoral Dissertation). Arizona State University, USA.

International Labour Office (2018). Global Skills Trends, Training Needs and Life long Learning Strategies for the Future of Work (International Labour Conference report). Geneva, Switzerland. Retrieved from https://www.ilo.org/wcmsp5/groups/public/--dgreports/---inst/documents/publication/wcms_646038.pdf

Irani, L. (2018). "Design Thinking": Defending Silicon Valley at the Apex of Global Labor Hierarchies. Catalyst, Feminism, Theory, Technoscience, 4(1), 1-19. https://doi/org/10.28968/cftt.v4i1.29638

Kassim, H. \& Ali, F. (2010). English communicative events and skills needed at the workplace: Feedback from the industry. English for Specific Purposes, 29 (3), 168-182. https://doi.org/10.1016/j.esp.2009.10.002 
Korostelina K. V. (2013). Identity and power in Ukraine. Journal of Eurasian Studies, 4(1), 3446.https://doi.org/10.1016/j.euras.2012.10.002

Lee, S. \& Tony, Ma. (2007). An analysis of cultural differences upon project team performance for global projects. Proceedings of Australian Institute of Project Management National Conference 2007. Hobart, Tasmania. Retrieved from https://www.researchgate.net/publication/308063794_An_analysis_of_cultural_differences_upon_project_team_performance_f or_global_projects

Loeng, S. (2018). Various ways of understanding the concept of andragogy. Cogent Education, 5(1). https://doi.org/10.1080/2331186X.2018.1496643

Matveev, A.V., \& Milter, R.G. (2004). The value of intercultural competence for performance of multicultural teams. Team Performance Management, 10(5/6), 104-111. https://doi.org/10.1108/13527590410556827

Mayer, M. \& Bello, Y. (2012). Leading cross cultural teams in today's global marketplace. Paper presented at PMI ${ }^{\circledR}$ Global Congress 2012-EMEA, Marsailles, France. Newtown Square, PA: Project Management Institute. Retrieved from https://www.pmi.org/learning/library/cross-cultural-teams-global-marketplace-6304

McCauley, K. D., Hammer, E., \& Hinojosa, A.S. (2017). An Andragogical Approach to Teaching Leadership. Managemant Teaching Review, 2(4), 312-324. https://doi.org/10.1177/2379298117736885

McGrath, V. (2009). Reviewing the Evidence on How Adult Students Learn: An Examination of Knowles' Model of Andragogy. The Irish Journal of Adult and Community Education, 99-110. Retrieved from https://eric.ed.gov/?id=EJ860562

Meyer, E. (2014). The culture map: breaking through the invisible boundaries of global business ( $1^{\text {st }}$ ed.). New York, USA: PublicAffairs.

Moore, K.A.,\& Pearson, B.J. (2017). Soft Skills in an Online Class. Hort Technology, $27(5)$, 583-585. https://doi.org/10.21273/HORTTECH03672-17

Robles, M.M. (2012). Executive perceptions of the top 10 soft skills needed in today's workplace. Business Communication Quarterly, 75(4), 453-465.https://doi.org/10.1177/1080569912460400

Romanutskyi, V. (2014). Individualist and collectivist priorities of Ukrainian culture in empirical studies. National Academy of Managerial Staff of Culture and Arts Herald, 1, 95 - 101. https://doi.org/10.32461/2226-3209.1.2014.137901

Kalytchak, R., Kharlamova, G., Klimenkova, O., Lutsenko, O., Paschenko, S., Pavlenko, V., \& Senyk, O. (2015). Soft Skills: Academic Guide/Teaching Materials. Northumbria University, UK: Shoo Fly Publishing. Retrieved from https://www.donnu.edu.ua/wpcontent/uploads/sites/8/2018/07/Material-1.pdf

Sperling, J. \& Tucker, R.W. (2005). For-profit higher education: developing a world-class workforce. New Jersey, USA: Transaction Publishers.

Swartz, S., Barbosa, B., \& Crawford, I. (2019). Building intercultural competence through virtual team collaboration across global classrooms. Business Communication Quarterly, 1(23), 57-79. https://doi.org/10.1177/2329490619878834

Trompenaars, F., \& Hampden-Turne, C. (2020). Riding the Waves of Culture: Understanding Diversity in Global Business (4 ${ }^{\text {th }}$ ed.). New York, USA: McGraw-Hill.

Vitto, C. D. (2008). Cross-Cultural "Soft Skills" and the Global Engineer: Corporate Best Practices and Trainer Methodologies. Online Journal for Global Engineering Education, 3(1). Retrieved from http://digitalcommons.uri.edu/ojgee/vol3/iss1/1http://digitalcommons.uri.edu/ojgee/vol3/iss1/1

Whatley, J. (2016). Live Projects: A Case to Present Concepts and Benefits. In J. Whatley \& C. Nerantzi (Eds.), Teaching with team projects in higher education. Santa Rosa,CA, USA: Informing Science Press.

Young, L. (2014). Ukraine: Individualistic or Collectivistic? Retrieved from https://sites.psu.edu/worldwidewomen/ukraineindividualistic-or-collectivistic/

Zheng, M. (2015). Intercultural Competence in Intercultural Business Communication. Open Journal of Social Sciences, 3, 197200.https://doi.org/10.4236/jss.2015.33029

Zimmermann, K. (2010). Intercultural competence as a success factor of virtual multicultural teams: a case study on the team effectiveness of global HR teams. Mastere's Thesis, University of Jyväskylä. Retrieved from https://www.semanticscholar.org/paper/Intercultural-competence-as-a-succes-factor-of-\%3A-a-

Zimmermann/4eeb42d7474757d9df06da1a63e93de54bacf52d

Received: October 20, 2020

Accepted: April 19, 2021 


\section{APPENDIX A}

SURVEY FORM

Student's Name

(optional)

Grade your progress in the following business communication / 'soft' skills, using a 10-point scale:

\begin{tabular}{|c|c|c|c|c|c|c|c|c|c|c|c|}
\hline \multirow[t]{2}{*}{ Type of Skills } & $\mathbf{0}$ & 1 & 2 & 3 & 4 & 5 & 6 & 7 & 8 & 9 & 10 \\
\hline & \begin{tabular}{|l|} 
No \\
progress \\
at all
\end{tabular} & $\begin{array}{l}\text { Hardly } \\
\text { noticeable } \\
\text { progress }\end{array}$ & \begin{tabular}{|l|}
$\begin{array}{l}\text { Slight } \\
\text { progress }\end{array}$ \\
\end{tabular} & $\begin{array}{l}\text { Noticeable } \\
\text { progress }\end{array}$ & \begin{tabular}{|l|} 
Visible \\
progress
\end{tabular} & $\begin{array}{l}\text { Moderate } \\
\text { progress }\end{array}$ & \begin{tabular}{|l|} 
Higher \\
than \\
average \\
progress
\end{tabular} & \begin{tabular}{|l|} 
Good \\
progress
\end{tabular} & \begin{tabular}{|l|}
$\begin{array}{l}\text { Remarkable } \\
\text { progress }\end{array}$ \\
\end{tabular} & \begin{tabular}{|l|} 
High \\
progress
\end{tabular} & \begin{tabular}{|l|}
$\begin{array}{l}\text { Outstanding } \\
\text { progress }\end{array}$ \\
\end{tabular} \\
\hline \multicolumn{12}{|l|}{ Team building } \\
\hline \multicolumn{12}{|l|}{$\begin{array}{l}\text { Teamwork/ } \\
\text { Team coordination }\end{array}$} \\
\hline \multicolumn{12}{|l|}{ Knowledge management } \\
\hline \multicolumn{12}{|l|}{ Problem solving } \\
\hline \multicolumn{12}{|l|}{$\begin{array}{l}\text { Conflict prevention/ } \\
\text { resolution }\end{array}$} \\
\hline \multicolumn{12}{|l|}{ Presentation skills } \\
\hline \multicolumn{12}{|l|}{ Negotiation skills } \\
\hline \multicolumn{12}{|l|}{$\begin{array}{l}\text { Managing emotions / } \\
\text { emotional intelligence }\end{array}$} \\
\hline
\end{tabular}

1) Share your experiences, emotions and attitudes about Team Learning:

2) Provide recommendations for further improvement of Team Learning: 


\section{APPENDIX B}

EVALUATION OF THE STUDENTS' PROGRESS IN BUSINESS COMMUNICATION/ 'SOFT SKILLS'

Researcher (Teacher) _____ (optional)

\begin{tabular}{|l|l|l|l|l|l|l|l|l|l|l|}
\hline Type of Skills & $\mathbf{0}$ & $\mathbf{1}$ & $\mathbf{2}$ & $\mathbf{3}$ & $\mathbf{4}$ & $\mathbf{5}$ & $\mathbf{6}$ & $\mathbf{7}$ & $\mathbf{8}$ & $\mathbf{9}$ \\
\hline
\end{tabular}




\section{APPENDIX C}

EVALUATION OF THE STUDENTS' PROGRESS IN ENGLISH LANGUAGE COMMUNICATION SKILLS Researcher (Teacher) (optional)

\section{Group}

\begin{tabular}{|c|c|c|}
\hline Student's name & Type of skills & max. 20 points \\
\hline & Statement of one's ideas & \\
\hline & Persuasion & \\
\hline & Active and comprehensive listening & \\
\hline & Requesting information & \\
\hline & Expressing evaluations and emotions & \\
\hline \multirow[t]{6}{*}{ Total: } & & $/ 100$ points \\
\hline & Statement of one's ideas & \\
\hline & Persuasion & \\
\hline & Active and comprehensive listening & \\
\hline & Requesting information & \\
\hline & Expressing evaluations and emotions & \\
\hline \multirow[t]{6}{*}{ Total: } & & $/ 100$ points \\
\hline & Statement of one's ideas & \\
\hline & Persuasion & \\
\hline & Active and comprehensive listening & \\
\hline & Requesting information & \\
\hline & Expressing evaluations and emotions & \\
\hline Total: & & $/ 100$ points \\
\hline
\end{tabular}

